\title{
Blood pressures in subjects for life assurance medical examination and the effect of ten minutes recumbent rest
}

\author{
${ }^{1}$ CDR Pengelly, ${ }^{2} \mathrm{~J}$ Morris \\ ${ }^{1}$ Physician, Altrincham; ${ }^{2}$ Head of Medical Statistics, University Hospital of South Manchester, UK
}

\begin{abstract}
Background: The prevalence of hypertension in a population is the sum of those individuals with a blood pressure (BP) exceeding $140 / 90 \mathrm{~mm} \mathrm{Hg}$ plus those with normal BP on antihypertensive therapy (this is usually about $20-30 \%$ of the population). Rest normally reduces BP but the frequency and extent of the fall remains unclear.
\end{abstract}

Methods: This study analysed the results of 1,008 consecutive life assurance examinations in which BP was recorded twice, before and after a ten minute period of recumbent rest.

Results: Two hundred and twelve subjects had initial BPs of more than 140/90 $\mathrm{mm} \mathrm{Hg}(2 \mathrm{l} \%)$. When all those receiving antihypertensive treatment but with normal BPs were included, this was $26.5 \%$. Of the 212 subjects, BP was at a normal level in 147 (69\%) after ten minutes at rest.

Conclusion: BP measurement after a ten minute period of standardised rest could more accurately identify true hypertension.

KEYWORDS Life assurance medicals, blood pressure, effect of rest, hypertension

DECLARATION OF INTERESTS No conflicts of interest declared.
Correspondence to CDR Pengelly, Consulting Rooms 60 Manchester Road Altrincham WAI4 4PJ e-mail cdrpengellyal@aol.com

\section{INTRODUCTION}

Blood pressures (BPs) recorded at the time of life assurance medical examinations provide an opportunity to assess normal levels in a generally healthy population. Normal BP can be defined as 140/90 millimetres of mercury $(\mathrm{mm} \mathrm{Hg})$ or less; with 24-hour ambulatory monitoring, $135 / 85 \mathrm{~mm} \mathrm{Hg}$ is the threshold and between 130/85 and 135/85 $\mathrm{mm} \mathrm{Hg}$ is regarded as the average daytime level.' For 'office' BPs (taken during a standard appointment) it is recommended that the true BP level should be based on three separate visits and that a sufficient interval is allowed each time for the BP level to become stable: five minutes is suggested with the subject sitting. ${ }^{2}$ The subjects' position, whether sitting or recumbent during the rest period is not regarded as critical. ${ }^{3.4}$

The prevalence of hypertension in a population is conventionally estimated by adding those subjects with initial BPs of more than $140 / 90 \mathrm{~mm} \mathrm{Hg}$ to those with normal BPs on antihypertensive therapy. It is estimated globally as $13.5 \%$ of the population. ${ }^{5}$ Larger proportions (between $20 \%$ and $30 \%$ ) have been found in the USA, Canada and the UK and higher still with subjects of Afro-Caribbean and Asian origin. ${ }^{6-10}$

Life assurance companies normally request a single BP reading from applicants for life cover and unless the reading exceeds $140 / 90 \mathrm{~mm} \mathrm{Hg}$ it is not repeated. When the BP level is more than $140 / 90 \mathrm{~mm} \mathrm{Hg}$ insurers request two further recordings, after intervals of five and ten minutes, with the subject at rest. Most life assurance companies will accept a BP of I40/90 mm $\mathrm{Hg}$ or less after ten minutes rest as being normal. However, the proportion whose BP is initially above 140/90 mm Hg and who reach non-hypertensive levels is not clear.

In a previous study, BP levels in 640 subjects at life assurance medical examination were reviewed." In $23 \%$ of cases the initial BP was more than $140 / 90 \mathrm{~mm} \mathrm{Hg}$. In about $70 \%$ of these the BP fell to less than $140 / 90 \mathrm{~mm}$ $\mathrm{Hg}$ after ten minutes rest. This study analysed subjects seen before 1997, none of whom are included in the current study. In a later study we looked at BPs in another 342 life assurance applicants and found that ten minutes rest (after the first BP reading) resulted in a significant fall in the systolic or mean BP in $84 \%$ of subjects (unpublished results). The current study was undertaken to record initial and ten minute BPs in every case and includes the 342 subjects mentioned above.

We compared our results against both the life assurance companies' normal maximum value of $140 / 90 \mathrm{~mm} \mathrm{Hg}$ and with the accepted daytime ambulatory level (I35/85 mm Hg). ${ }^{12}$ 


\section{SUBJECTS AND METHODS}

\section{Subjects}

During the period 1997-2010 I,021 applicants for life assurance policies had their BP taken. Blood pressures were recorded twice, with the second reading taken after ten minutes recumbent rest. Thirteen subjects were rejected, leaving 1,008 for analysis. Of these 13 subjects, in eight BP was not recorded at ten minutes and five were known to be pregnant and were therefore omitted due to the uncertain effect of pregnancy on BP.

Our analysis is therefore based on 1,008 subjects. The majority (936) were Caucasians. Of the 72 individuals of alternative ethnic origin, 62 were from the Indian subcontinent, five were Chinese or Indonesian and five were from Africa or the West Indies. One hundred and five subjects were receiving antihypertensive therapy. Full details of the I,008 subjects are shown in Table I.

\section{Methods}

Subjects were reassured about the procedure as much as possible. All subjects were sent a preliminary letter containing practical and procedural information. On arrival at the consulting office the subjects spent between five and ten minutes in the waiting room. The temperature of the premises was always $21^{\circ} \mathrm{C}\left(70^{\circ} \mathrm{F}\right)$ or above.

Blood pressure recording: Blood pressures were taken with a mercury sphygmomanometer and a standard cuff with a bladder measuring $14 \mathrm{~cm} \times 24 \mathrm{~cm}$. If the subjects had thick upper arms a larger cuff with a bladder measuring $15 \mathrm{~cm} \times 27 \mathrm{~cm}$ was used. The aim was to allow the bladder to encircle $80 \%$ of the upper arm and two-thirds of its length. ${ }^{2}$

Blood pressures were taken with the subjects recumbent and measurements were to the nearest $5 \mathrm{~mm} \mathrm{Hg}$. Two measurements were taken from the right arm, first at the end of the physical examination and then ten minutes later. A third reading was taken from the left arm to ensure there was no gross difference between sides (all differences were less than $5 \mathrm{~mm} \mathrm{Hg}$ ).

Statistical analysis: Differences in BP between males and females were assessed using the two-sample t-test. Initial and ten minute BPs were compared with the paired t-test. Pearson correlations were used to describe the relationship between age and BP.

TABLE I Age distribution by ethnicity and gender

\begin{tabular}{|c|c|c|c|c|c|}
\hline \multirow{2}{*}{$\begin{array}{l}\text { Ethnicity } \\
\text { and } \\
\text { gender }\end{array}$} & \multicolumn{5}{|c|}{ Age (years) } \\
\hline & Number & Mean & $\begin{array}{l}\text { Standard } \\
\text { deviation }\end{array}$ & Minimum & Maximum \\
\hline All cases & 1,008 & 46.3 & 10.5 & 23 & 82 \\
\hline Male & 787 & 46.4 & 10.2 & 23 & 82 \\
\hline Female & 221 & 45.9 & 11.6 & 23 & 78 \\
\hline Caucasian & 936 & 46.6 & 10.6 & 23 & 82 \\
\hline Male & 736 & 46.6 & 10.3 & 23 & 82 \\
\hline Female & 200 & 46.4 & 11.6 & 23 & 78 \\
\hline Non-Caucasian & 72 & 42.4 & 9.2 & 26 & 76 \\
\hline Male & 51 & 42.6 & 8.2 & 26 & 65 \\
\hline Female & 21 & 41.3 & 11.5 & 26 & 76 \\
\hline $\begin{array}{l}\text { From Indian } \\
\text { subcontinent }\end{array}$ & 62 & 42.3 & 9.0 & 26 & 76 \\
\hline Male & 47 & 42.6 & 8.3 & 26 & 65 \\
\hline Female & 15 & 41.5 & 11.3 & 29 & 76 \\
\hline $\begin{array}{l}\text { African or } \\
\text { West Indian }\end{array}$ & 5 & 42.6 & 11.5 & 31 & 62 \\
\hline Male & 2 & 39.5 & 0.7 & 39 & 40 \\
\hline Female & 3 & 44.7 & 15.8 & 31 & 62 \\
\hline $\begin{array}{l}\text { Chinese or } \\
\text { Indonesian }\end{array}$ & 5 & 42.8 & 11.4 & 26 & 53 \\
\hline Male & 2 & 51.5 & 2.1 & 50 & 53 \\
\hline Female & 3 & 37.0 & 11.5 & 26 & 49 \\
\hline
\end{tabular}




\section{RESULTS}

Age, ethnicity and gender details are in Table I. The main results are analysed in Tables $2-4$. We have compared our BP levels both with the life assurance companies' normal maximum value $(140 / 90 \mathrm{~mm} \mathrm{Hg})$ and with the accepted daytime ambulatory level (I35/85 mm Hg).

Initial blood pressures: From the cohort of I,008 subjects, 796 (79\%) had initial BPs equal to, or less than, I 40/90 mm Hg; 2 I 2 (2I\%) had BPs exceeding that level. Further analysis showed that 105 (10.4\%) were on antihypertensive therapy and 903 (89.6\%) were not.

Mean systolic and diastolic BPs for the above groups are given in Table 2 together with 95\% confidence intervals. The mean initial systolic and diastolic BPs for all subjects were $131.3 \mathrm{~mm} \mathrm{Hg}$ and $79.1 \mathrm{~mm} \mathrm{Hg}$. For those on antihypertensive medication these levels were $142.4 \mathrm{~mm}$ $\mathrm{Hg}$ and $85.3 \mathrm{~mm} \mathrm{Hg}$ and for those not on antihypertensive treatment, $130.0 \mathrm{~mm} \mathrm{Hg}$ and $78.4 \mathrm{~mm} \mathrm{Hg}$, respectively. The BP levels are analysed by gender in Table 3. Initial systolic and diastolic BPs were higher in males compared to females by 8.0 and $5.4 \mathrm{~mm} \mathrm{Hg}$, respectively; both differences were highly significant $(p<0.001)$.

The effect of ten minutes rest on blood pressure: In subjects with an initial BP of greater than $140 / 90 \mathrm{~mm}$ $\mathrm{Hg}, \mathrm{I} 47$ (69.3\%) of them fell to less than $140 / 90 \mathrm{~mm} \mathrm{Hg}$ after ten minutes rest, and $73(34.4 \%)$ to $135 / 85 \mathrm{~mm} \mathrm{Hg}$ or less; in those whose initial BP was equal to or less than $140 / 90 \mathrm{~mm} \mathrm{Hg}, 770$ (96.7\%) were equal to or less than $135 / 85 \mathrm{~mm} \mathrm{Hg}$ after ten minutes rest.

In those subjects with initial BPs of equal to or less than $140 / 90 \mathrm{~mm} \mathrm{Hg}$, $99.9 \%$ remained at or below 140/90 mm Hg. Only one had a BP level of over I40/90 $\mathrm{mm} \mathrm{Hg}$ after ten minutes $(0.1 \%)$. The reason for this was not clear. Mean changes in systolic and diastolic BPs after ten minutes rest were highly significant $(p<0.00 \mathrm{I})$ and overall, subjects had a mean percentage reduction of $4.9 \%$ in systolic BP and $4.3 \%$ in diastolic BP (Table 2).

Effects of antihypertensive therapy: Subjects on antihypertensive medication (105) showed systolic and diastolic BP reductions after ten minutes rest of $6.7 \%$ and $4.7 \%$ respectively, whereas those not receiving this treatment showed reductions of $4.7 \%$ and $4.3 \%$ respectively (Table 2 ).

The prevalence of hypertension: Initial BP readings showed that $212(21 \%)$ of the I,008 subjects had levels greater than $140 / 90 \mathrm{~mm} \mathrm{Hg}$. Fifty of these were receiving antihypertensive treatment, but a further 55 on antihypertensive therapy had initial BPs of I40/90 mm $\mathrm{Hg}$ or less. The antihypertensive medications that the 105 subjects were taking are shown in Table 4 . The accepted way of estimating the degree of hypertension in a population is to add those with initial BPs of more

TABLE 2 Blood pressure details for 1,008 subjects including those on and not on antihypertensive medication

\begin{tabular}{|c|c|c|c|c|c|c|}
\hline \multicolumn{4}{|c|}{ Systolic blood pressure (mm Hg) } & \multicolumn{3}{|c|}{ Diastolic blood pressure $(\mathrm{mm} \mathrm{Hg})$} \\
\hline Subjects & Mean & $\begin{array}{c}95 \% \\
\text { confidence } \\
\text { interval }\end{array}$ & p value* & Mean & $\begin{array}{c}95 \% \\
\text { confidence } \\
\text { interval }\end{array}$ & Mean \\
\hline \multicolumn{7}{|l|}{ All subjects $(1,008)$} \\
\hline Initial blood pressure & 131.3 & 130.3 to 132.2 & & 79.1 & 78.5 to 79.7 & \\
\hline 10 minute blood pressure & 124.5 & 123.7 to 125.2 & & 75.6 & 75.0 to 76.1 & \\
\hline Change in blood pressure & -6.8 & -7.3 to -6.4 & $<0.001$ & -3.5 & -3.8 to -3.3 & $<0.001$ \\
\hline Change in blood pressure (\%) & -4.9 & -5.2 to -4.6 & $<0.001$ & -4.3 & -4.6 to -4.0 & $<0.001$ \\
\hline \multicolumn{7}{|l|}{$\begin{array}{l}\text { Subjects on antihypertensive } \\
\text { medication (105) }\end{array}$} \\
\hline Initial blood pressure & 142.4 & 139.6 to 145.2 & & 85.3 & 83.7 to 86.9 & \\
\hline 10 minute blood pressure & 132.4 & 130.0 to 134.6 & & 81.1 & 79.6 to 82.6 & \\
\hline Change in blood pressure & -10.0 & -11.8 to -8.2 & $<0.001$ & -4.2 & -5.2 to -3.2 & $<0.001$ \\
\hline Per cent change in blood pressure (\%) & -6.7 & -7.8 to -5.5 & $<0.001$ & -4.7 & -5.8 to -3.6 & $<0.001$ \\
\hline \multicolumn{7}{|l|}{$\begin{array}{l}\text { Subjects not on antihypertensive } \\
\text { medication ( } 903)\end{array}$} \\
\hline Initial blood pressure & 130.0 & 129.0 to 131.0 & & 78.4 & 77.6 to 79.0 & \\
\hline 10 minute blood pressure & 123.5 & 122.7 to 124.4 & & 74.9 & 74.4 to 75.5 & \\
\hline Change in blood pressure & -6.5 & -6.9 to -6.0 & $<0.001$ & -3.5 & -3.7 to -3.2 & $<0.001$ \\
\hline Per cent change in blood pressure (\%) & -4.7 & -5.0 to -4.4 & $<0.001$ & -4.3 & -4.6 to -3.9 & $<0.001$ \\
\hline
\end{tabular}


TABLE 3 Blood pressure levels in subjects by gender

\begin{tabular}{|c|c|c|c|c|c|c|}
\hline \multirow[t]{2}{*}{ Subjects } & \multicolumn{2}{|c|}{$\begin{array}{l}\text { Blood pressures } \\
>140 / 90 \mathrm{~mm} \mathrm{Hg}\end{array}$} & \multicolumn{2}{|c|}{$\begin{array}{l}\text { Blood pressures } \\
\leq 140 / 90 \mathrm{~mm} \mathrm{Hg}\end{array}$} & \multicolumn{2}{|c|}{$\begin{array}{l}\text { Blood pressures } \\
\leq 135 / 85 \mathrm{~mm} \mathrm{Hg}\end{array}$} \\
\hline & Number & Per cent & Number & Per cent & Number & Per cent \\
\hline $\begin{array}{l}\text { Male (787) } \\
\text { Initial } \\
\text { blood pressure }\end{array}$ & 181 & 23.0 & 606 & 77.0 & 500 & 63.5 \\
\hline $\begin{array}{l}10 \text { minute } \\
\text { blood pressure }\end{array}$ & 58 & 7.4 & 729 & 92.6 & 640 & 81.3 \\
\hline $\begin{array}{l}\text { Female (22I) } \\
\text { Initial } \\
\text { blood pressure }\end{array}$ & 31 & 14.0 & 190 & 86.0 & 177 & 80.1 \\
\hline $\begin{array}{l}10 \text { minute } \\
\text { blood pressure }\end{array}$ & 8 & 3.6 & 213 & 96.4 & 203 & 91.9 \\
\hline
\end{tabular}

TABLE 4 Antihypertensive therapy in 105 subjects on medication

\begin{tabular}{|l|c|}
\hline \multicolumn{1}{|c|}{ Subjects on one medication } & No. \\
\hline ACE inhibitor & 25 \\
\hline Beta blocker & 18 \\
\hline Diuretic & 7 \\
\hline Angiotensin 2 blocker & 7 \\
\hline Ca channel blocker & 5 \\
\hline Alpha blocker & 3 \\
\hline Unspecified (subject did not know) & I \\
\hline \multicolumn{1}{|c|}{ Subjects on two medications } & 7 \\
\hline ACE inhibitor + beta blocker & 5 \\
\hline Diuretic + beta blocker & 4 \\
\hline Diuretic + ACE inhibitor & 3 \\
\hline Diuretic + angiotensin 2 blocker & 2 \\
\hline Diuretic + alpha blocker & 2 \\
\hline ACE inhibitor + alpha blocker & 2 \\
\hline ACE inhibitor + Ca channel blocker & I \\
\hline Angiotensin 2 blocker + alpha blocker & I \\
\hline Angiotensin 2 blocker + Ca channel blocker & I \\
\hline Alpha blocker + Ca channel blocker & I \\
\hline Beta blocker + Ca channel blocker & I \\
\hline Diuretic + Ca channel blocker & I \\
\hline \multicolumn{1}{|c|}{ Subjects on three medications } \\
\hline Diuretic + beta blocker + ACE inhibitor & \\
\hline Diuretic + ACE inhibitor + Ca channel blocker & \\
\hline Diuretic + aldosterone inhibitor + vasodilator & \\
\hline Diuretic + beta blocker + alpha blocker & I \\
\hline ACE inhibitor + beta blocker + Ca channel \\
blocker
\end{tabular}

than $140 / 90 \mathrm{~mm} \mathrm{Hg}$ to those with normal BPs on antihypertensive therapy. In our study, this gives 267 subjects, which is $26.5 \%$ of the cohort.

\section{The effect of ten minutes rest on blood pressure:} Two hundred and twelve of our subjects had initial BPs of more than $140 / 90 \mathrm{~mm} \mathrm{Hg}$ and in 147 of these, BP fell to $140 / 90 \mathrm{~mm} \mathrm{Hg}$ or less after ten minutes. One subject with a normal initial BP had a BP greater than $140 / 90$ $\mathrm{mm} \mathrm{Hg}$ after ten minutes rest. In total, 66 subjects $(6.5 \%)$ had raised $\mathrm{BP}$ after ten minutes rest.

Age and blood pressure: We found that BP tended to rise with increasing age. Pearson correlations with initial systolic and diastolic BPs and with the ten minute levels showed values which were all highly significant $(p<0.001)$. However, the actual correlation coefficients were quite low, ranging from 0.23 to 0.28 .

Patterns of blood pressure: Of the 212 subjects with initial BPs of more than $140 / 90 \mathrm{~mm} \mathrm{Hg}, 152$ (7I.7\%) had isolated systolic hypertension and $59(27.8 \%)$ had both systolic and diastolic hypertension. There was only one example of isolated diastolic hypertension. The effect of ten minutes recumbent rest on the whole series resulted in BPs of $140 / 90 \mathrm{~mm} \mathrm{Hg}$ or less in $93.5 \%$ and $135 / 85 \mathrm{~mm} \mathrm{Hg}$ or less in $83.6 \%$ of all subjects.

Ethnicity and blood pressure: There were 72 (7.1\%) non-Caucasian subjects in our series. Of these, only six (8.3\%) had initial BPs of greater than $140 / 90 \mathrm{~mm} \mathrm{Hg}$ (Table 5).

Sixty-two subjects were from the Indian sub-continent and six $(9.7 \%)$ of these had initial BPs of greater than I $40 / 90 \mathrm{~mm} \mathrm{Hg}$. Of the five subjects of native African or West Indian origin and five of Chinese or Indonesian origin, none had initial BPs greater than $140 / 90 \mathrm{~mm} \mathrm{Hg}$. The effect of rest on the BPs of the initially hypertensive subjects of Indian ethnic origin are shown in Table 5 . In two cases $(33 \%)$ the BP did not fall to a non-hypertensive level, a roughly similar proportion to the whole series. 
TABLE 5 Initially hypertensive non-Caucasian subjects

\begin{tabular}{|c|c|c|c|c|}
\hline Gender & Age (years) & $\begin{array}{c}\text { Initial blood } \\
\text { pressure } \mathbf{( m m} \mathbf{~ H g})\end{array}$ & $\begin{array}{c}\text { I } \text { minute blood } \\
\text { pressure } \mathbf{( m m ~ H g )}\end{array}$ & Ethnic origin \\
\hline Male & 45 & $155 / 100$ & $135 / 90$ & Indian \\
\hline Male & 45 & $170 / 100$ & $135 / 85$ & Indian \\
\hline Male & 42 & $145 / 85$ & $145 / 85$ & Indian \\
\hline Male & 45 & $160 / 100$ & $140 / 90$ & Indian \\
\hline Male & 65 & $150 / 90$ & $145 / 85$ & Indian (born in Kenya) \\
\hline Male & 56 & $145 / 80$ & $135 / 80$ & Indian \\
\hline "on antihypertensive medication
\end{tabular}

\section{DISCUSSION}

The purpose of this study was to show the frequency and degree of lowering of BP achievable with ten minutes recumbent rest, the beneficial effect of which is well known in life assurance companies.

Although most BPs are usually recorded with the subject sitting, we used the recumbent posture as this was better suited to the conditions of medical examination. There is little evidence that $\mathrm{BP}$ readings are significantly affected by change of posture from sitting to lying but the topic is still controversial. ${ }^{3,4,12,13}$

Normal BP on a single or repeated initial 'office' reading is usually accepted as $140 / 90 \mathrm{~mm} \mathrm{Hg}$ or less. Recently it has been suggested that there is an element of prehypertension in subjects with BP levels between $120 / 80$ $\mathrm{mm} \mathrm{Hg}$ and $139 / 89 \mathrm{~mm} \mathrm{Hg}{ }^{14}$ This is a controversial concept and prompts the question, 'Are we all hypertensive now?'. ${ }^{5}$

We have shown that about a fifth (212) of the 1,008 subjects in our study had initial BPs greater than $140 / 90$ $\mathrm{mm} \mathrm{Hg}$ and that, of those, approximately $70 \%$ fell to 140/90 mm Hg or less with ten minutes rest; about onethird fell to $135 / 85 \mathrm{~mm} \mathrm{Hg}$ or less, levels regarded as normal for daytime BPs taken by continuous ambulatory monitoring. In other words, only $6.4 \%$ of the hypertensive subjects were still considered hypertensive after ten minutes rest and in roughly half of these, the BP was equal to or less than $135 / 85 \mathrm{~mm} \mathrm{Hg}$. In those whose BP was initially equal to or less than $140 / 90 \mathrm{~mm} \mathrm{Hg}$, nearly $97 \%$ were at $135 / 85 \mathrm{~mm} \mathrm{Hg}$ or less after ten minutes rest.

The accepted method of measuring the proportion of hypertensive people in a population is to assume that all those on antihypertensive therapy are truly hypertensive. The number of subjects with initial BPs of more than $140 / 90 \mathrm{~mm} \mathrm{Hg}$ and those with normal BPs on antihypertensive treatment in our study make up $26.5 \%$ of the cohort. Our data on initial BPs agree with other findings, supporting a prevalence of hypertension in between $20-30 \%$ of the population. ${ }^{5-10}$ However, when those subjects with raised initial BPs which fell to normal are eliminated, the prevalence is reduced to $15.5 \%$.

Kaplan and Victor ${ }^{16}$ point out that even if advice on taking BP is followed, almost all the data on the risks of hypertension are based on only one or a few 'office' readings in large groups of people.

The National Institute for Health and Clinical Excellence (NICE) has recently published new draft guidelines for diagnosing and treating high BP. ${ }^{17}$ They recommend that 24-hour ambulatory BP monitoring (ABPM) or home BP monitoring (HPBM) should be offered to all those whose readings are more than $140 / 90 \mathrm{~mm} \mathrm{Hg}$ and they should be offered antihypertensive treatment if they have target organ damage. However, they accept that not all patients with two readings of more than $140 / 90 \mathrm{~mm}$ $\mathrm{Hg}$ are truly hypertensive.

Blood pressure taken after ten minutes rest is much more likely to represent a subject's true BP level compared with the initial readings. Therefore we consider that a diagnosis of hypertension should not be made unless the BP remains raised after a full ten minutes rest in a physically and psychologically comfortable environment.

\section{CONCLUSION}

Surveys indicate that about $30 \%$ of the population are hypertensive $(>140 / 90 \mathrm{~mm} \mathrm{Hg})$ based on an initial reading. When medically examining candidates for life assurance policies, ten minutes recumbent rest significantly reduces the number showing hypertension, by about two-thirds. Many with initial BPs of less than 140/90 $\mathrm{mm} \mathrm{Hg}$ also show a significant reduction.

\section{Acknowledgements}

We are grateful to Professor Peter Whorwell for helpful criticism, to Mrs Sigrid Whiteside for help in compiling the statistical data and to Mrs Susan Alboutany for typing the manuscript. 


\section{REFERENCES}

I Mancia G, De Backer G, Dominiczak A et al. Guidelines for the management of arterial hypertension: the taskforce for the management of arterial hypertension of the European Society of Hypertension (ESH) and of the European Society of Cardiology. Eur Heart J 2007; 28: | 462-536.

2 Kaplan NM, Victor RG. Kaplan's clinical hypertension. Philadelphia: Wolters Kluwer Lippincott Williams and Wilkins; 2010. p. 30.

3 Reeves RA. The rational clinical examination. Does this patient have hypertension? How to measure blood pressure. JAMA 1995; 273: I 2 I I-8.http://dx.doi.org/ I0. I00 I/jama. I 995.0352039007/036

4 Brackenridge RDC, Elder WJ. Medical selection of life risks. 4th ed. London: Macmillan Reference; 1998. pp. 22I-3.

5 Lawes CM, Vander Hoorn S, Rodgers A. Global burden of bloodpressure-related disease, 200I. Lancet 2008; 37I:I5I3-8. http:// dx.doi.org/I0.1016/S0I40-6736(08)60655-8

6 Whelton PK, Adams-Campbell LL, Appel LJ et al. National high blood pressure education program working group report on primary prevention of hypertension. Arch Intern Med 1993; I53 I86-208. http://dx.doi.org/I0.100 I/archinte.1993.004I0020042003

7 Fryer CD, Hirsch R, Eberhardt MS et al. Hypertension, high serum total cholesterol and diabetes: racial and ethnic prevalence differences in U.S. adults 1996-2006. National Center for Health Statistics Data Brief 2010; 36:2-7.

8 Wolz M, Cutler J, Roccella EJ et al. Statement from the national high blood pressure education program: prevalence of hypertension. Am J Hypertens 2000; 13:103-4. http://dx.doi.org/10.1016/S0895706I(99)0024I-I
9 Leenen HH, Dumais J, Mclnnis NH et al. Results of the Ontario survey on the prevalence and control of hypertension. CMAJ 2008; I78:|44|-9. http://dx.doi.org//0.1503/cmaj.07/340

10 Lane D, Beevers DG, Lip GY. Ethnic differences in blood pressure and the prevalence of hypertension in England. J Hum Hypertens 2002; 16:267-73. http://dx.doi.org/10.1038/sj.jhh. I00I37I

II Pengelly CDR, Winstanley J. Blood pressure in life assurance medical examinations. A review of 640 cases. Bolton Medical Journal 1999; 13:25-32.

12 O'Brien ET, Beevers DG, Marshall HJ. ABC of hypertension. 3rd ed. London: BMJ Publishing Group; 1995. p. 10.

13 Beevers DG, Lip GY, O'Brien E. ABC of hypertension. 5th ed. Oxford: Blackwell Publishing and BMJ Books; 2007. p. 18.

14 Kaplan NM, Victor RG. Kaplan's clinical hypertension. Philadelphia: Wolters Kluwer Lippincott Williams and Wilkins Health; 20I0. p. 109.

I5 Moynihan R. Who benefits from treating pre-hypertension? BMJ 2010; 341:484-5. http://dx.doi.org/l0.II36/bmj.c4442

16 Kaplan NM, Victor RG. Kaplan's clinical hypertension. Philadelphia: Wolters Kluwer Lippincott Williams and Wilkins Health; 2010. p. 30-3.

17 National Institute for Health and Clinical Excellence. NICE consults on new guideline for diagnosing and treating high blood pressure [Internet]. London: NICE; 201 I [cited 2012 June 7].Available from: http://www.nice.org.uk/newsroom/pressreleases/NewGuideline ForDiagnosingAndTreatingHighBloodPressure.jsp

\section{Exclusive offer for RCPE Collegiate Members $\mathbf{5 0 \%}$ discount on Fellowship subscriptions}

We are pleased to offer a significant discount in annual subscription rates for eligible Collegiate Members who are Consultants and wish to progress to Fellowship. * Collegiate Members of four years' standing who are successful in their nomination for Fellowship will be able to obtain a $50 \%$ discount on their first year's Fellowship subscription and a $25 \%$ reduction on their second year's subscription, offering savings of up to $£ 300$.

Please access details of our reduced subscription rates, including concessionary elements for Fellows working less than halftime or on maternity leave, at: www.rcpe.ac.uk/join/ fellowshipoffer.php

\section{Fellowship confers a range of additional benefits and opportunities:}

- International peer and public recognition through the use of the 'FRCP Edin' postnominals.

- Professional support for revalidation/ recertification.

- The opportunity to participate in projects and working groups to determine the future direction of education and clinical medicine.

- The opportunity to help maintain national and international clinical standards by acting as an MRCP(UK) examiner.

- The opportunity to inform College responses to external policy consultations in your specialty.

- The opportunity to participate in the governance of the College through election to committees and to Council.

*Eligible candidates should normally have held a substantive Consultant post or equivalent for at least $\mathbf{1 1}$ months. If you hold such a post and are interested in being considered for Fellowship, the principal method is nomination by an existing Fellow. Please e-mail Avril Harries at a.harries@rcpe.ac.uk for a list of Fellows in your area. Alternatively, you may wish to discuss nomination with one of our Regional Advisers or consider self-nomination. 